\title{
CRIAÇÃO E VIDA NAS FRONTEIRAS DA REPRESENTAÇÃO - INTERLOCUÇÔES ENTRE AS EXPERIMENTAÇÕES TEATRAIS E OS ESTUDOS DA TRANSICIONALIDADE
}

A presente dissertação procura abordar os múltiplos sentidos da relação entre vida e criação a partir de um encontro entre psicologia e teatro. Através de uma reflexão sobre a noção de transicionalidade, proposta por Donald Winnicott, em diálogo com autores e artistas da cena teatral, este estudo procura compreender de que modo a formação da subjetividade se dá em um espaço de experimentação, no jogo paradoxal entre continuidade e ruptura com os signos culturais.

\section{BANCA:}

Maria Inês Garcia de Freitas Bittencourt (Orientadora)

Alvaro de Pinheiro Gouvêa

Rosyane Trotta

Data da defesa: 6/04/2010 